\title{
BUDAYA ORGANISASI, INSENTIF, KEPUASAN KERJA, DAN KINERJA KARYAWAN PADA PT AVRIST ASSURANCE
}

\author{
Iha Haryani Hatta dan Widarto Rachbini \\ Fakultas Ekonomi dan Bisnis Universitas Pancasila, Jakarta \\ Surel: iha.haryani@yahoo.com
}

\begin{abstract}
The purpose of this study was to determine the effect of organizational culture and incentive on job satisfaction and employees' performance. The study was conducted in PT Avrist Assurance, using 211 employees as respondents. The sampling technique in this research is simple random. The analysis was performed with Structural Equation Model (SEM) using Lisrel 8.5. The study found that organizational culture and incentives significantly affect job satisfaction and employees' performance. Moreover, job satisfaction significantly affect employees' performance. The total effect of organizational culture on Job Satisfaction and employee performance is more dominant than the total effect of incentives on Job Satisfaction and employee performance.
\end{abstract}

Keywods: Organizational Culture, Incentive, Job Satisfaction, Employees Performance

\begin{abstract}
Abstrak: Tujuan penelitian ini adalah untuk mengetahui pengaruh budaya organisasi dan insentif terhadap kepuasan kerja dan kinerja karyawan. Penelitian dilakukan di PT Avrist Assurance, dengan menggunakan 211 karyawan sebagai responden.Teknik pengambilan sampel dalam penelitian ini dilakukan secara acak sederhana. Analisis dilakukan dengan Structural Equation Model (SEM) menggunakan Lisrel 8.5. Hasil penelitian menemukan adanya pengaruh yang signifikan antarabudaya organisasi dan insentif terhadap kepuasan kerja dan kinerja karyawan, serta pengaruh yang signifikan antarakepuasan kerja terhadap kinerja karyawan. Pengaruh total budaya organisasi terhadap kepuasan kerja dan kinerja karyawan lebih dominan daripada pengaruh total insentif terhadap kepuasan kerja dankinerja karyawan.
\end{abstract}

Kata Kunci: Budaya Organisasi, Insentif, Kepuasan Kerja, Kinerja Karyawan

\section{PENDAHULUAN}

Pada saat ini kompetisi antar perusahaan semakin kompetitif sehingga perusahaan yang mempunyai strategi terbaiklah yang tetap survive. Setiap langkah perusahaan untuk mengembangkan diri dapat dengan mudah ditiru oleh perusahaan lain sehingga tidak dapat dipertahankan lagi menjadi keunggulan kompetitif secara terus menerus. Tetapi sebaliknya SDM merupakan sumber keunggulan kompetitif yang potensial karena kompetisi yang dimiliki berupa intelektual, sifat, keterampilan, karakter personal serta proses intelektual dan kognitif tidak dapat di tiru oleh perusahaan lain. Pengelolaan sumber daya manusia secara baik merupakan salah satu kunci keberhasilan organisasi.Sumber daya manusia merupakan faktor terpenting dalam menjalankan aktivitas perusahaan di samping alat-alat yang digunakan.

Menyadari pentingnya tenaga kerja bagi perusahaan maka perusahaan harus memberikan perhatian yang khusus pada karyawannya.Perusahaan perlu memahami dan 
mengetahui kebutuhan karyawannya, karena kebutuhan hidup karyawan merupakan salah satu alasan yang menyebabkan iabekerja. Menurut Utomo (2009), bila kebutuhan karyawan terpenuhi, maka mereka akan mendapat kepuasan yang akhirnya dapat mempengaruhi kinerja karyawan. Karena itu sebagai konsekuensinya perusahaan harus mengelola karyawan dengan baik melalui pemberian insentif untuk memotivasi karyawan agar meningkatkan kinerjanya.Menurut Rivai (2007), insentif secara sengaja diberikan kepada para karyawan agar di dalam diri mereka timbul semangat yang lebih besar untuk meningkatkan prestasi kerja sehingga produktivitas dan kinerjanya meningkat. Pemberian insentif di dalam suatu perusahaan memegang peranan penting karena diyakini akan dapat mengatasi berbagai permasalahan ditempat kerja yang semakin kompleks seperti rendahnya kinerja dan tidak adanya tambahan pendapatan bagi karyawan selain gaji. Menurut Mangkunegara (2007), bagi perusahaan adanya pemberian insentif diharapkan dapat meningkatkan kinerja karyawan, produktivitas kerja, loyalitas, disiplin, rasa tanggung jawab terhadap jabatan dan semakin baiknya mutu kepemimpinannya. Bagi karyawan dengan adanya pemberian insentif mereka memperoleh kesempatan untuk menambah pendapatan.

Setiap perusahaan memiliki budaya organisasi. Menurut Wirawan (2007), banyak organisasi yang bisa bertahan terhadap berbagai perubahan serta tantangan eksternal karena memiliki kekuatan budaya, atau sebaliknya banyak organisasi yang roboh karena tidak memiliki kekuatan budaya organisasi. Budaya organisasi berpengaruh terhadap kepuasan kerja (Koesmono 2005) dan berpengaruh terhadap kinerja pegawai(Prihayanto 2012).

Tentang pengaruh budaya organisasi, insentif terhadap kepuasan kerja dan kinerja karyawan pada penelitian terdahulu menunjukan belum ada konsistensi pengaruh antar variabel tersebut. Penelitian Soedjono (2005)mengungkapkan ada pengaruh signifikan antar budaya organisasi terhadap kepuasan kerja.Sedangkan temuan Widyarini (2009) bahwa budaya organisasi mempunyai pengaruh yang negatif terhadap kepuasan kerja. Penelitian Kulyana (2010) terdapat pengaruh positif dan signifikan antara insentif terhadap kepuasan kerja. Temuan Mariam (2009) bahwa terdapat pengaruh kepuasan kerja terhadap kinerja perusahaan adalah sinifikan dan positif.

Penelitian yang telah ada belum melakukan pengujian secara komprehensip pengaruh budaya organisasi dan insentif terhadap kepuasan kerja dan kinerja karyawan.Berdasarkan uraian di atas, maka tujuan yang ingin dicapai pada penelitian ini adalah mengetahui pengaruh budaya organisasi dan insentif terhadap kepuasan kerja dan kinerja karyawan, serta pengaruh kepuasan kerja terhadap kinerja karyawan.

\section{KAJIAN TEORI}

Budaya Organisasi. Menurut Wirawan (2007), budaya organisasi adalah: "Norma, nilainilai, asumsi, kepercayaan, filsafat, kebiasaan organisasi, dan sebagainya yang dikembangkan dalam waktu yang lama oleh pendiri, pemimpin dan anggota organisasi yang disosialisasikan dan diajarkan kepada anggota baru serta ditetapkan dalam aktivitas organisasi sehingga mempengaruhi pola pikir, sikap dan perilaku anggota organisasi dalam memproduksi produk, melayani para konsumen dan mencapai tujuan organisasi". Menurut Dessler (2008), budaya organisasi menjadi pembeda suatu organisasi dengan organisasi lainnya. Menurut Rivai (2007), fungsi budaya organisasi memiliki suatu peran menetapkan tapal batas, artinya budaya menciptakan perbedaan yang jelas antara satu 
orang dengan orang lain; budaya memberikan identitas bagi anggota organisasi; budaya mempermudah timbulnya komitmen-komitmen yang lebih luas dan pada kepentingan individu; budaya itu meningkatkan kemantapan sosial; budaya sebagai mekanisme pembuat makna dan kendali yang memandu serta membentuk sikap dan perilaku karyawan. Menurut Wirawan (2007), unsur-unsur pembentukbudaya organisasi di antaranya adalah lingkungan usaha, nilai-nilai, pahlawan, ritual, dan jaringan budaya.

Insentif.Selain gaji yang diberikan kepada karyawan, biasanya ada tambahan yang diberikan oleh perusahaan kepada karyawan yang dinamakan insentif.Insentif diberikan di luar upah atau gaji yang diterima oleh karyawan pada setiap bulannya.Menurut Mangkunegara (2007), tujuan pemberian insentif adalah untuk meningkatkan produktivitas kerja karyawan serta mempertahankan karyawan yang berprestasi agar tetap bekerja di perusahaan tersebut. Insentif dapat menjadi motivator bagi karyawan perusahaan agar lebih bersemangat dalam bekerja, sehingga dapat meningkatkan kinerja. Insentif adalah "suatu penghargaan dalam bentuk uang yang diberikan oleh pihak pimpinan organisasi kepada karyawan agar dapat bekerja dengan motivasi yang tinggi dan prestasi dalam mencapai tujuan organisasi”. Beberapa sifat dasar insentif yang harus dipenuhi agar sistem upah dapat berhasilyaitu pembayarannya hendaknya sederhana, sehingga dapat dimengerti dan dihitung oleh karyawan sendiri; penghasilan yang diterima oleh karyawan hendaknya langsung menaikkan output dan efisiensi; pembayarannya hendaknya dilakukan secepat mungkin; standar kerja hendaknya ditentukan dengan hatihati karena standar kerja yang terlalu tinggi atau terlalu rendah sama tidak baiknya; besarnya upah normal dengan standar kerja per jam hendaknya cukup merangsang pekerja untuk bekerja lebih giat. Insentif merupakan suatu pendorong untuk melakukan tindakan pencapaian tujuan.

Kepuasan Kerja. Menurut Rivai (2007), ketika seorang bekerja pada suatu organisasi, instansi, ataupun perusahaan maka hasil kerja yang ia selesaikan akan memengaruhi tingkat produktivitas organisasi. Oleh karena itu, pandangan dan juga perasaan individu terhadap pekerjaannya harus tetap terjaga pada sisi positif dari pekerjaannya. Dengan ungkapan lain, individu tersebut harus memiliki dan menjaga kepuasan kerjanya agar produktivitasnya dapat terus ditingkatkan.Menurut Siregar (2006), kepuasan kerja merupakan suatu kumpulan dari perasaan atau emosi yang menyenangkan atau tidak yang ditunjukan oleh karyawan dalam bekerja.Hasibuan(2006), kepuasan kerja adalah sikap emosional yang menyenangkan dan mencintai pekerjaannya.Sikap ini dicerminkan oleh moral kerja, kedisiplin, dan prestasi kerja. Kepuasan kerja dinikmati di dalam pekerjaan, di luar pekerjaan, dan kombinasi antara keduanya.Kepuasan kerja karyawan dipengaruhi oleh faktor-faktor antara lain balas jasa yang layak dan adil, penempatan yang tepat sesuai dengan keahlian, berat-ringannya pekerjaan, suasana dan lingkungan pekerjaan, peralatan yang menunjang pelaksanaan pekerjaan, sikap pemimpin dalam kepemimpinannya, dan sifat pekerjaan monoton atau tidak.

Kinerja Karyawan. Menurut Ruky (2006), kinerja sering diartikan sebagai pencapaian tugas. Kinerja karyawan menunjukkan hasil kerja seseorang secara keseluruhan selama periode tertentu dibandingkan dengan berbagai kemungkinan.Menurut Ivancevich(2007), karyawan dalam bekerja harus sesuai dengan program kerja organisasi untuk menunjukkan tingkat kinerja organisasi dalam mencapai visi, misi, dan tujuan organisasi. 
Menurut Dessler (2008), penilaian kinerja berarti memberikan umpan balik kepada karyawan dengan tujuan memotivasi karyawan untuk menghilangkan penurunan kinerja atau terus bekerja lebih giat. Menurut Sedarmayanti (2008), penilaian pelaksanaan kinerja adalah sistem yang digunakan untuk menilai dan mengetahui apakah seorang karyawan telah melaksanakan pekerjaan secara keseluruhan. Penilaian kinerja karyawan meliputi kualitas pekerjaan yangberkaitan dengan ketelitian dan standar kualitas yang telah ditetapkan, ketepatan waktu dalam menyelesaikan pekerjaan, keberanian dalam menyampaikan pernyataan atau pendapat, dan kepuasan yang diambil dalam menghadapi atau menyelesaikan masalah.

Berdasarkan uraian pada kajian teori dan hasil penelitian yang relevan dibuat skema penelitian yang menggambarkan hubungan antar variabel sebagai berikut.

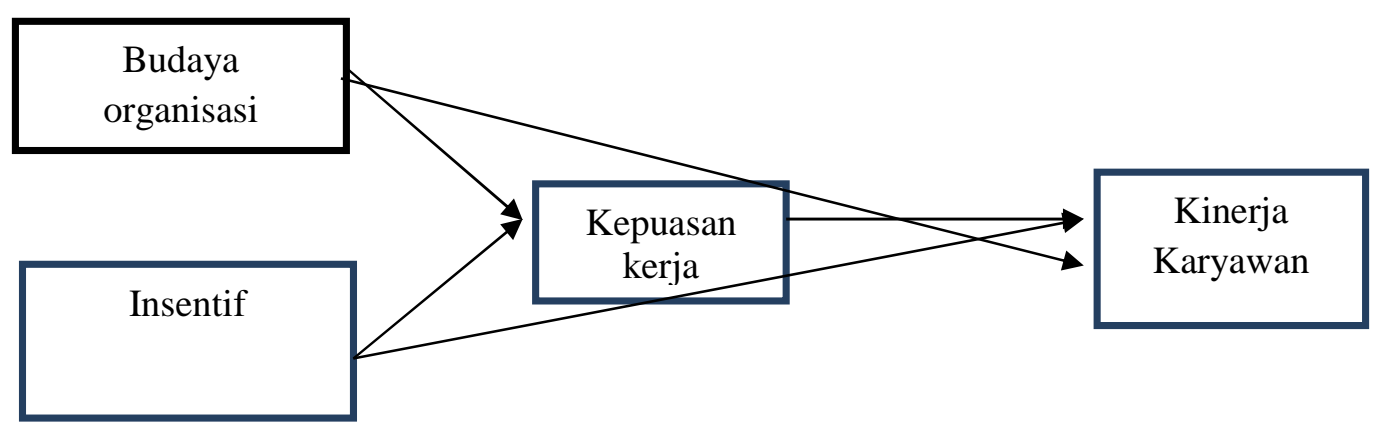

Gambar 1. Skema Penelitian

Hipotesis.Dalam penelitian ini akan membahas tentang pengaruh budaya organisasi dan insentif terhadap kepuasan kerja dan dampaknya terhadap kinerja karyawan. Hipotesis pada penelitian ini:

1. Budaya organisasi mempunyai pengaruh terhadap kepuasan kerja

2. Budaya organisasi mempunyai pengaruh terhadap kinerja karyawan

3. Insentif mempunyai pengaruh terhadap kepuasan kerja

4. Insentif mempunyai pengaruh terhadap kinerja karyawan

5. Kepuasan kerja mempunyai pengaruh terhadap kinerja karyawan

\section{METODE}

Desain penelitian yang digunakan dalam penelitian ini adalah penelitian kausalyang tujuan utamanya adalah untuk membuktikan pengaruh variabel budaya organisasi dan insentif terhadap kepuasan kerja dan kinerja karyawan; Pengaruh kepuasan kerja terhadap kinerja karyawan. Operasionalisasi variabel penelitian ini sebagai berikut variabel endogen Budaya Organisasi (BUDORG) menggunakan indikator yaitu misi, konsistensi, adaptabilitas, dan pelibatan. Variabel endogen insentif (INSENTIF) menggunakan indikator yaitu memenuhi kebutuhan, menimbulkan semangat, serta bersifat adil dan layak; Variabel eksogen kepuasan kerja (KEPKERJA) menggunakan indikator yaitu pekerjaan itu sendiri, pembayaran (gaji-insentif), supervisi, kesempatan untuk promosi, dan rekan sekerja; Variabel eksogen kinerja karyawan (KINKAR). menggunakan 
indikator yaitu pengetahuan tentang pekerjaan, kuantitas, kualitas, ketepatan waktu insentif, pengambilan keputusan. Skala pengukuran variabel penelitian ini adalah skala interval..

Populasi pada penelitian ini adalah 260 orang karyawan tetap PT Avrist Assurance.Data diperoleh melalui survey, dipilihsebagai sampel atau responden sebanyak 211 orang secara acak sederhana. Jawaban kuesioner yang diperoleh dari responden diuji terlebih dahulu dengan uji normalitas. Uji tersebut bertujuan untuk mengetahui distribusi data dalam variabel yang akan digunakan mengikuti atau mendekati distribusi normal. Data yang baik adalah data yang mempunyai pola distribusi normal.Analisis normalitas dilakukan dengan uji Klomogrov-Smirnov. Menurut Umar (2008), kriteria keputusan distribusi normal sebagai berikut: Jika nilai asymp. sig (2-tailed) $>0.05$ maka tidak mengalami gangguan distribusi normal. Jika nilai asymp.sig (2-tailed) $<0.05$ maka mengalami gangguan distribusi normal.

Untuk menentukan kategori persepsi responden di interval kelas adalah (nilai tertinggi - nilai terendah)/jumlah kelas atau (5-1)/5=0.8. Sehingga kategori persepsi responden terhadap variabel penelitian sebagai berikut:Jawaban 1,00 - 1,80 termasuk kategori penilaian sangat rendah atau sangat tidak setuju; Jawaban 1,81 - 2,60 termasuk kategori penilaian rendah atau tidak setuju; Jawaban 2,61 - 3,40 termasuk kategori penilaian sedang atau netral; Jawaban 3,41 - 4,20 termasuk kategori penilaian tinggi atau setuju; Jawaban 4,21 - 5,00 termasuk kategori penilaian sangat tinggi atau sangat setuju.

Teknik analisis data penelitian ini adalah Structural Equation Model (SEM) dengan menggunakan program Lisrel 8.5.Pengujian persamaan pengukuran pada penelitian ini menggunakan kriteria (Umar 2008), jika faktor loading berada di atas 0,6 atau koefisien determinasi $\mathrm{R}^{2}>0,36$ maka instrumen pengukuran dapat dikatakan bermakna/valid. Jika tidak memenuhi maka instrumen dikatakan tidak valid secara konstruk, sehingga dapat dieliminasi. Selanjutnya dievaluasi reliabilitas model pengukuran, bila nilai CR $>0,70$ dan VE >0,5 maka variabel penelitian tersebut dikatakan reliable. Selanjutnya dibuat model Struktural dan Hybrid (Standardized) serta analis Goodness of Fit (GoF).

\section{HASIL DAN PEMBAHASAN}

Karakteristik responden pada penelitian ini sebagai berikut: kebanyakan responden berjenis kelamin perempuan $(59,72 \%)$, sisanya $(40,28 \%)$ berjenis kelamin pria. Kebanyakan responden berusia > 26 tahun (72,04\%), sisanya berusia 20-25 tahun $(27,96 \%)$. Semua berpendidikan perguruan tinggi yaitu akademi (D3, S1, dan Pascasarjana)

Persepsi responden terhadap budaya organisasi adalah sangat tinggi, nilai rata-rata variabel budaya organisasi sebesar 4,08. Persepsi responden terhadap pemberian insentif adalah tinggi, nilai rata-rata variabel pemberian insentif sebesar 3,98.Persepsi responden terhadap kepuasan kerja adalah sangat tinggi, nilai rata-rata variabel kepuasan kinerja sebesar 4.20.Persepsi responden terhadap kinerja karyawan adalah tinggi, nilai rata-rata variabel kinerja karyawan sebesar 4.08.

Hasil uji normalitas pengaruh budaya organisasi dan insentif terhadap kepuasan kerja menunjukkan bahwa nilai asymp.sig (2-tailed) adalah 0.401 diatas nilai signifikan 0.05. Sehingga dapat dikatakan bahwa variabel residual berdistribusi normal, lihat Tabel 1. 
Tabel 1. Hasil Uji Normalitas

Pengaruh Budaya Organisasi dan Insentif Terhadap Kepuasan Kerja

One-Sample Kolmogorov-Smirnov Test

\begin{tabular}{llr}
\hline & & Unstandardized Residual \\
\hline $\mathrm{N}$ & & 211 \\
Normal Parameters $^{\mathrm{a}, \mathrm{b}}$ & Mean & .0000000 \\
& Std. Deviation & 4.35950715 \\
Most Extreme Differences & Absolute & .131 \\
& Positive & .079 \\
& Negative & -.131 \\
Kolmogorov-Smirnov Z & & 1.906 \\
Asymp. Sig. (2-tailed) & & .401 \\
\hline
\end{tabular}

Hasil uji normalitas pengaruh budaya organisasi dan insentif terhadap kinerja karyawan menunjukkan bahwa nilai asymp.sig. (2-tailed) adalah 0,279 di atas nilai signifikan 0,05 . Sehingga dapat diambil keputusan bahwa variabel residual berdistribusi normal, lihat Tabel 2.

Tabel 2. Hasil Uji Normalitas

Pengaruh Budaya Organisasi dan Insentif Terhadap Kinerja Karyawan

One-Sample Kolmogorov-Smirnov Test

\begin{tabular}{llr}
\hline & & \multicolumn{2}{c}{$\begin{array}{c}\text { Unstandardized } \\
\text { Residual }\end{array}$} \\
\hline $\mathrm{N}$ & & 211 \\
Normal Parameters ${ }^{\mathrm{a}, \mathrm{b}}$ & Mean & .0000000 \\
& Std. Deviation & 2.18664099 \\
Most Extreme Differences & Absolute & .068 \\
& Positive & .058 \\
& Negative & -.068 \\
Kolmogorov-Smirnov Z & & .992 \\
Asymp. Sig. (2-tailed) & & .279 \\
\hline
\end{tabular}

Pada variabel budaya organisasi terdapat 10 indikator, 6 di antaranya dikatakan valid. Variabel budaya organisasi dikatakan reliabel karena memiliki $\mathrm{CR}=0,82$ dan VE $=$ 0,54; Variabel insentif memiliki 10 indikator, 8 indikator di antaranya valid.Variabel ini reliabel karena memiliki $\mathrm{CR}=0,89$ dan $\mathrm{VE}=0,51$; Ada 10 indikator pada variabel kepuasan kinerja, 5 indikator di antaranya valid. Variabel ini reliabel karena memiliki CR $=0,081$ dan $\mathrm{VE}=0,79$; Ada 8 indikator pada variabel kinerja karyawan, 2 indikator di antaranya valid. Variabel ini reliabel karena memiliki $\mathrm{CR}=0,72$ dan $\mathrm{VE}=0,71$

Model struktural menunjukkan besarnya pengaruh variabel-variabel laten serta koefisien-koefisien terhadap variabel laten lain yang dijabarkan pada tabel 3dibawah ini. 
Tabel 3. Model Persamaan Struktural

\begin{tabular}{|c|c|c|c|}
\hline No. & Persamaan & $\begin{array}{c}\text { Error } \\
\text { var }\end{array}$ & $\mathrm{R}^{2}$ \\
\hline 1 & KEPKERJA $=0.64 *$ BUDORG $+0.14 *$ INSENTIF & 0.48 & 0.52 \\
\hline 2 & KINKAR $=0.16 *$ KEPKERJA+0.67*BUDORG+0.15*INSENTIF & 0.23 & 0.77 \\
\hline
\end{tabular}

Pada persamaan KEPKERJA dikatakan bahwa variabel budaya organisasi dan insentif dapat memberikan sumbangan terhadap variabel kepuasan kerja sebesar 0,52atau $52 \%\left(\mathrm{R}^{2}=0.52\right)$. Variabel lain yang tidak di masukkan dalam model penelitian ini dapat menjelaskan variabel kepuasan kerja sebesar 48\%.Pada persamaan KINKAR diketahui bahwa variabel budaya organisasi, insentif dan kepuasan kerja dapat memberikan sumbangan terhadap variabel kinerja karyawan sebesar 0,77 atau $77 \%\left(\mathrm{R}^{2}=0.76\right)$. Variabel lain yang tidak dimasukkan dalam model penelitian ini dapat menjelaskan variabel kinerja karyawan sebesar $23 \%$

Berdasarkan hasil persamaan pengukuran dan struktural di atas maka dibuat model standardized yang dapat dilihat pada Gambar 2.

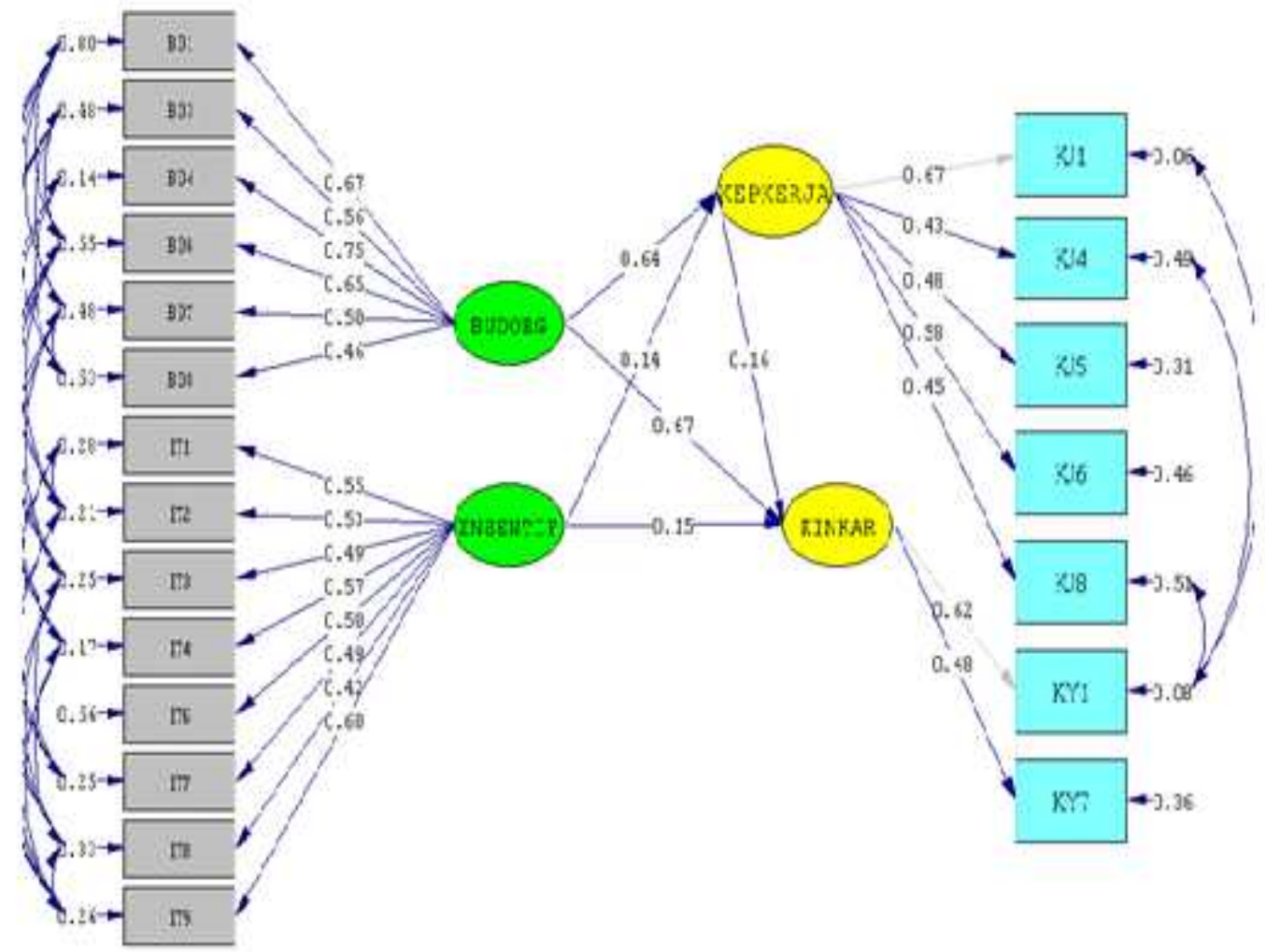

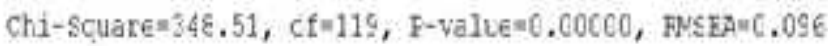

Gambar 2. Model Standardized 
Berdasarkan analisis Goodness of Fit (GoF) dapat dilihat bahwa melalui $\chi 2$, NFI,NNFI, CFI, maka model dapat dikatakan memiliki kecocokan yang baik. Lihat Tabel4.

Tabel 4. Hasil Uji Kecocokan Model Keseluruhan dengan GoF

\begin{tabular}{ccccc}
\hline Fit Measure & Good Fit & Marginal Fit & $\begin{array}{c}\text { Score } \\
\text { Research }\end{array}$ & Result \\
\hline$\chi 2$ & $\leq 419.69$ & & 348.51 & Fit \\
RMSEA & $0 \leq$ RMSEA $\leq 0.05$ & $0.05<$ RMSEA $\leq 0.08$ & 0.096 & No Fit \\
RMR & $0 \leq$ RMR $\leq 0.05$ & $0.05<$ RMR $\leq 0.8$ & 0.060 & Marginal Fit \\
NFI & $0.90 \leq$ NFI $\leq 1.00$ & $0.85<$ NFI $\unlhd 0.90$ & 0.93 & Good Fit \\
NNFI & $0.90 \leq$ NNFI $\leq 1.00$ & $0.85<$ NNFI $\unlhd 0.90$ & 0.90 & Good Fit \\
CFI & $0.90 \leq$ CFI $\leq 1.00$ & $0.85<$ CFI $\unlhd 0.90$ & 0.95 & Good Fit \\
GFI & $0.90 \leq$ GFI $\leq 1.00$ & $0.80<$ GFI $\unlhd 0.90$ & 0.86 & Marginal Fit \\
AGFI & $0.90 \leq$ AGFI $\leq 1.00$ & $0.80<$ AGFI $\unlhd 0.90$ & 0.74 & No Fit \\
\hline
\end{tabular}

Hubungan kausal antar variabel tergantung pada nilai distribusinya t-nya. Menurut Umar (2008), bila nilai distribusinya t-hitung lebih besar daripada t-tabel pada $\alpha=5 \%$ sebesar 1.96, maka pengaruh variabel yang dihipotesiskan dalam penelitian ini secara statistika hipotesis ditolak atau hipotesis alternatif diterima, begitu pula sebaliknya. Pengujian hipotesis dengan uji $\mathrm{t}$ dijabarkan pada Tabel 5.

Tabel 5. Uji t

\begin{tabular}{|c|c|c|c|}
\hline Hipotesis & Pernyataan Hipotesis & $\mathrm{t}$-value & Keterangan \\
\hline $\mathrm{H}_{1}$ & $\begin{array}{l}\text { Pengaruh budaya organisasi terhadap } \\
\text { kepuasan kerja }\end{array}$ & 8,77 & $\mathrm{H}_{1}$ diterima \\
\hline $\mathrm{H}_{2}$ & Pengaruh insentif terhadap kepuasan kerja & 2,06 & $\mathrm{H}_{2}$ diterima \\
\hline $\mathrm{H}_{3}$ & $\begin{array}{l}\text { Pengaruh budaya organisasi terhadap kinerja } \\
\text { karyawan }\end{array}$ & 7,95 & $\mathrm{H}_{3}$ diterima \\
\hline $\mathrm{H}_{4}$ & Pengaruh insentif terhadap kinerja karyawan & 3,93 & $\mathrm{H}_{4}$ diterima \\
\hline $\mathrm{H}_{5}$ & $\begin{array}{l}\text { Pengaruh kepuasan kerja terhadap kinerja } \\
\text { karyawan }\end{array}$ & 2,28 & $\mathrm{H}_{5}$ diterima \\
\hline
\end{tabular}

Pada variabel budaya organisasi terdapat indikator yang dominan (faktor loading > 0.60) yaitu karyawan bekerja maksimal,pimpinan taat pada Peraturan Kepegawaian dan karyawan terbuka yang memberikan pengaruh langsung terhadap kepuasan kerja (0.64) dan memberikan pengaruh langsung terhadap kinerja karyawan ( 0.67). Keragaman nilai variabel budaya organisasi memberikan dukungan terhadap keragaman nilai kepuasan kerja dan kinerja karyawan. Hasil penelitian ini senada dengan penelitian Soedjono (2005), Widyarini (2009) serta Brahmasari\& Suprayetno (2008)bahwa budaya organisasi 
mempunyai pengaruh terhadap kepuasan kerja; sesuai dengan penelitian Dalimunthe (2009) dan Prihayanto (2012) serta Brahmasari\& Suprayetno (2008) bahwa budaya organisasi mempunyai pengaruh terhadap kinerja karyawan.

Pada variabel insentif terdapat indikator yang dominan (faktor loading $>0.60$ ) yaitu kredit perumahan bagi karyawan yang memberikan pengaruh langsung terhadap kepuasan kerja (0.14) dan memberikan pengaruh langsung terhadap kinerja karyawan (0.15).Keragaman nilai variabel insentif memberikan sumbangan terhadap keragaman nilai kepuasan kerja dan kinerja karyawan. Hasil penelitian ini senada dengan penelitian Agustin (2010), Lantara \& Utomo (2014) bahwa insentif mempunyai pengaruh dengan kepuasan kerja;sesuai dengan penelitian Agustin (2010),Zaputri (2013), dan Erawati (2014)bahwa insentif mempunyai pengaruh terhadap kinerja karyawan.

Pada variabel kepuasan kerja terdapat indikator yang dominan (faktor loading > 0.60), yaitu puas dengan gaji dan bonus yang diterima.Indikator tersebut memberikan pengaruh langsung terhadap kinerja karyawan (0.15). Keragaman nilai variabel kepuasan kerja memberikan sumbangan terhadap keragaman nilai kinerja karyawan. Hasil penelitian ini senada dengan penelitian Utomo (2009) \& Ranihusna (2010) bahwa kepuasan kerja mempunyai pengaruh terhadap kinerja karyawan.

Berdasarkan Gambar 2 dapat diperoleh pengaruh tidak langsung antar variabel dalam penelitian ini. Pengaruh budaya organisasi terhadap kinerja karyawan melalui kepuasan kerja sebesar 0.10 (0.64 x 0.16).Pengaruh tersebut lebih besar dari pengaruh insentif terhadap kinerja karyawan melalui kepuasan kerja sebesar 0.02 ( 0.14 x 0.16 ). Pengaruh total adalah besarnya pengaruh variabel langsung ditambahkan dengan pengaruh variabel tidak langsung. Pengaruh budaya organisasi terhadap kinerja karyawan baik langsung maupun tidak langsung melalui kepuasan kerja sebesar $0.67+0.10=0.77$; Pengaruh insentif terhadap kinerja karyawan baik langsung maupun tidak langsung melalui kepuasan kerja sebesar $0.15+0.02=0.17$. Pengaruh total budaya organisasi terhadap kepuasan kerja (sebagai variable intervening) dan kinerja karyawan lebih dominan dibandingkan dengan pengaruh total insentif terhadap kepuasan kerja(sebagai variable intervening) dan kinerja karyawan. Hasil analisis pengaruh langsung, tidak langsung dan total di atas, disajikan dalam Tabel 6.

Tabel 6. Pengaruh Antar Variabel

\begin{tabular}{|c|c|c|c|c|c|c|}
\hline No. & Alur dari & $\mathrm{Ke}$ & $\begin{array}{c}\text { Variabel } \\
\text { Intervening }\end{array}$ & $\begin{array}{l}\text { Pengaruh } \\
\text { langsung }\end{array}$ & $\begin{array}{l}\text { Pengaruh } \\
\text { tidak } \\
\text { langsung }\end{array}$ & $\begin{array}{c}\text { Pengaruh } \\
\text { Total }\end{array}$ \\
\hline 1 & Budaya Organisasi & $\begin{array}{c}\text { Kinerja } \\
\text { Karyawan }\end{array}$ & $\begin{array}{c}\text { Kepuasan } \\
\text { Kerja }\end{array}$ & 0.67 & 0.10 & 0.77 \\
\hline 2 & Insentif & $\begin{array}{c}\text { Kinerja } \\
\text { Karyawan }\end{array}$ & $\begin{array}{c}\text { Kepuasan } \\
\text { Kerja }\end{array}$ & 0.15 & 0.04 & 0.17 \\
\hline
\end{tabular}

Untuk mencapai peningkatan kinerja karyawan, pimpinan perlu meningkatkan pendidikan dan pelatihan bagi karyawan agar karyawan memiliki pengetahuan tentang pekerjaannya. Di samping itu, pimpinan perusahaan harus lebih mengutamakan terbentuknya budaya organisasi yang baik melalui karyawan bekerja maksimal, pemimpin taat peraturan kepegawaian, dan karyawan terbuka.Kemudian pimpinan perusahaan hendaknya melaksanakan sistem insentif yang memadai terutama fasilitas pemberian kredit perumahan bagi karyawan. 


\section{PENUTUP}

Simpulan. Budaya organisasi berpengaruh terhadap kepuasan kerja dan kinerja karyawan.Insentif berpengaruh terhadap kepuasan kerja dan kinerja karyawan.Kepuasan kerja memberikan pengaruh terhadap kinerja karyawan.Pengaruh total budaya organisasi terhadap kepuasan kerja dan kinerja karyawan lebih dominan dari pada pengaruh total insentif terhadap kepuasan kerja dan kinerja karyawan.

Pimpinan perusahaan hendaknya meningkatkan program pendidikan dan pelatihan bagi karyawan, sehingga karyawan dapat bekerja lebih maksimal dan terbuka untuk bekerjasama; Kriteria kepemimpinan perusahaan harus orang yang telah cukup lama bekerja pada perusahaan tersebut, sehingga sudah diketahui karakter kepatuhannya pada peraturan dan menguasai pemahaman tentang masalah budaya organisasi, insentif dan kepuasan kerja; Perlu dilakukan penelitian lanjutan untuk lokasi yang berbeda atau penambahan variabel seperti motivasi dan karakteristik pekerjaan, atau variabel lain yang dapat berpengaruh terhadap kinerja karyawan.

\section{DAFTAR RUJUKAN}

Agustin, A.,C., Dewi. (2010) "Pengaruh Pemberian Insentif terhadap Kinerja Karyawan Melalui Kepuasan Kerja (Studi Pada Karyawan Persada Swalayan Malang)" Universitas Negeri Malang. Malang.

Brahmasari, I., A. dan A., Suprayetno. (2008) "Pengaruh Motivasi Kerja, Kepemimpinan dan Budaya Organisasi Terhadap Kepuasan Kerja Karyawan Serta Dampaknya pada Kinerja Perusahaan" (Studi Kasus Pada PT Pei Hai International Wiratama Indonesia). Jurnal Manajemen dan Kewirausahaan, Vol.10, (2), September 2008; 124-135.

Dalimunthe, A. Halim. (2009) "Pengaruh Budaya Organisasi Terhadap Kinerja Pegawai" (Studi Pada Dinas Informasi Komunikasi dan Pengolahan Data Elektronik Kota Medan). Skirpis, Fakultas Ilmu Sosial dan Ilmu Politik, Universitas Sumatera Utara, Medan.

Dessler, Gary. (2008) Manajemen Sumber Daya Manusia. Paramita Rahayu.

Erawati, F. (2014) "Pengaruh Supervisi, Lingkungan Kerja Dan Insentive Terhadap Kinerja Pegawai" (Studi Terhadap Accrunt Representative (AR) pada KPP Madya DKI Jakarta). Jurnal Bisnis \& Manajemen Eksekutif, Vol 1, (1), 2014, artikel 5.

Hasibuan. (2006) Manajemen Dasar, Pengertian dan Masalah, Edisi Revisi, Bumi Aksara. Jakarta.

Ivancevich, John M. (2007) Perilaku dan Manajemen Organisasi. Erlangga, Jakarta.

Koesmono, H.,T. (2005) "Pengaruh Budaya Organisasi Terhadap Motivasi Dan Kepuasan

Kerja Serta Kinerja Karyawan Pada Sub Sektor Industri Pengolahan Kayu Skala

Menengah di Jawa Timur". Jurnal Manajemen dan Kewirausahaan. Vol 7, (2), September 2005.

Kulyana, W. (2010) "Pengaruh Insentif Terhadap Kepuasan Kerja Karyawan Pada PT Tri

Bakti Sarimas Pekan Baru". Skripsi, Jurusan Manajemen Fakultas Ekonomi Universitas Islam Riau, Pekan Baru.

Lantara dan Utomo. (2014) "Pengaruh Insentif Finansial, Insentif Non Finansial Dan Lingkungan Kerja Terhadap Kepuasan Kerja Karyawan Pada PT Tiara Cipta Nirwana, E-Jurnal Manajemen Universitas Udayana, Vol 3, (4), 2014 hal 922-937. 
Mangkunegara. (2007) Manajemen Sumber Daya Manusia Perusahaan. Edisi 1. PT Remaja Rosdakarya, Bandung.

Mariam, R. (2009) "Pengaruh Gaya Kepemimpinan dan Budaya Organisasi Terhadap Kinerja Karyawan Melalui Kepuasan Kerja Karyawan Sebagai Variabel Intervening (Studi Pada Kantor Pusat PT Asuransi Jasa Indonesia (Persero)". Tesis. Program Studi Magister Manajemen Pascasarjana Universitas Diponegoro, Semarang.

Prihayanto. (2012) "Analisis Pengaruh Budaya Organisasi dan Motivasi Terhadap Kinerja Karyawan" (Studi Pada PT Telekomunikasi Indonesia, Tbk, Regional IV Jawa Tengah di Yogyakarta). Skripsi, Fakultas Ekonomi dan Bisnis Universitas Diponegoro, Semarang.

Ranihusna, D. (2010) "Efek Rantai Motivasi Pada Kinerja Karyawan". Jurnal Dinamika Manajemen, Vol 1, (2), 2010, hal 90-103.

Rivai, Veithzal. (2007) Manajemen Sumber Daya Manusia Untuk Perusahaan: Dari Teori ke Praktik. Raja Grafindo Persada, Jakarta.

Ruky, A.S. (2006) Sistem Manajemen Kinerja. Gramedia Pustaka Utama, Jakarta.

Sedarmayanti. (2008) Sumber Daya Manusia. Bumi Aksara, Jakarta.

Siregar, Dyah Dumasari. (2006) "Kepuasan Kerja VS Produktivitas". Majalah Eksekutif.

Soedjono. 2005. "Pengaruh Budaya Organisasi Terhadap Kinerja Organisasi dan Kepuasan Kerja Karyawan pada Terminal Penumpang Umum di Surabaya”. Jurnal Manajemen dan Kewirausahaan. Vol 7, (1).

Widyarini, D. (2009) "Pengaruh Budaya Organisasi Terhadap Kepuasan Kerja dan Kreatifitas Auditor/Pegawai Inspektorat Kabupaten Banjarnegara”. Tesis. Program Studi Magister Akuntansi, Pascasarjana, Universitas Diponegoro, Semarang.

Wirawan. (2007) Budaya dan Iklim Organisasi. Salemba Empat, Jakarta.

Umar, Husein. (2008) Desain Penelitian Serta Sumber Daya Manusia dan Perilaku Karyawan. Raja Grafindo, Jakarta.

Utomo, J. (2009). "Pengaruh Motivasi Kerja, Kepuasan Kerja, dan Komitmen Organisasional Terhadap Kinerja Pegawai" (Studi Pada Pegawai Setda Kabupaten Pati): Fakultas Ekonomi, Diponegoro, Semarang.

Zaputri, A., R. (2013) "Pengaruh Insentif Material \& Non Material Terhadap Kepuasan Kerja Karyawan" (Studi Pada Karyawan Produksi Cetak PT Temprium Media Grafika Di Surabaya). Jurnal Administrasi Bisnis. Vol 2, (2) (2013). 